\title{
APPROACHES OF EUROPEAN UNION COUNTRIES TO WASTE MANAGEMENT
}

\author{
Milena Botlíková1 ${ }^{1}$ \\ Josef Botlík ${ }^{2}$ (D)
}

DOI: https://doi.org/10.31410/tmt.2019.381

\begin{abstract}
The contemporary world is experiencing dynamic development of tourism, which is inseparably connected with positive impacts, such as employment growth, increase of business activities etc. On the other side we are actively discussing context of tourism and global issues in recent years. With the development of tourism occurs to overload of tourist destinations, causes increasing greenhouse gas emissions, and waste production. This is considered as one of the most serious global issues, right after the lack of water. One option of the effective dealing of corporate waste is the implementation of a waste management strategy in corporate governance. The aim was to compare development of waste production and recycling in the EU regions with emphasis on Czech Republic and compare the approach of Czech companies in tourism on waste management. Based on analysis can be stated that number of wastes gradually decreases, the share of waste recycling on a European scale is increasing. According to research is obvious that companies in tourism have certain reserves in waste management.
\end{abstract}

Keywords: Sustainability, Waste, EMAS.

\section{INTRODUCTION}

A $\mathrm{s}$ a result of globalization processes occurs to intensive development of tourism. Population lifestyle change, desire for knowledge, social statute or changes of the free time are the cause of mass tourism. Intense tourism brings positive but also negative impacts. In an effort to eliminate negative impacts, the concept of sustainable development is increasingly declining, it means that form of tourism, that „ensures that the current needs of tourism participants are met while helping to develop the territory“ (MRD, 2016). Development in context of sustainable tourism is possible only under the conditions of acceptance of these principles into individual companies' management; it means, that companies implement into their management social responsibility resulting from its own business. Social responsibility is defined as: „,voluntary integration of social and environmental considerations into day-to-day business operations and stakeholder interactions". From the definition is obvious that sustainable tourism and social responsibility of companies builds on identical economic, social and environmental pillars (see Figure 1, Kunz, 2012). From these definitions is possible to conclude that companies in tourism (not just them), in the interest of sustainable development should integrate principles of social responsibility into their business processes. Social responsibility of companies represents concept, when company as a part of its business activities takes over shares' responsibility for well-being and sustainable development, at the same time the company expecting the maintain its own competitiveness and economic profit, and these are not two conflicting goals. Companies incorporate principles of sustainable development into operation on a voluntary basis.

Faculty of Philosophy and Science in Opava, Bezručovo nám. 14, 74601 Opava, Czechia School of Business Administration in Karvina, Univerzitní náměstí 1934/3, 73340 Karviná, Czechia 
As far as the environmental point of view in concerned, it is unlike the economic or social point of view predominantly connected with negative influences. Environmental questions of sustainable development and social responsibility in waste management concern the sorting and minimization of waste, its recycling or reuse. The individual theories of sustainable development tend to comply with the following measures: do not use resources beyond their recovery capacity, where a renewable resource can be used then no non-renewable resource and no natural resources should be used to exceed Earth's assimilation capacity as a result of waste disposal. Priority aim of everyone, whether you are an individual, a company or the whole society, in waste management should bet the elimination of waste generation followed by waste management. Every business strategy should include a „3R“ model (Reduce, Reuse, Recycle). Kelly (2007) warns that customers who want to travel are more environmentally friendly and that the introduction of environmental and social program is part of the choice of accommodation.

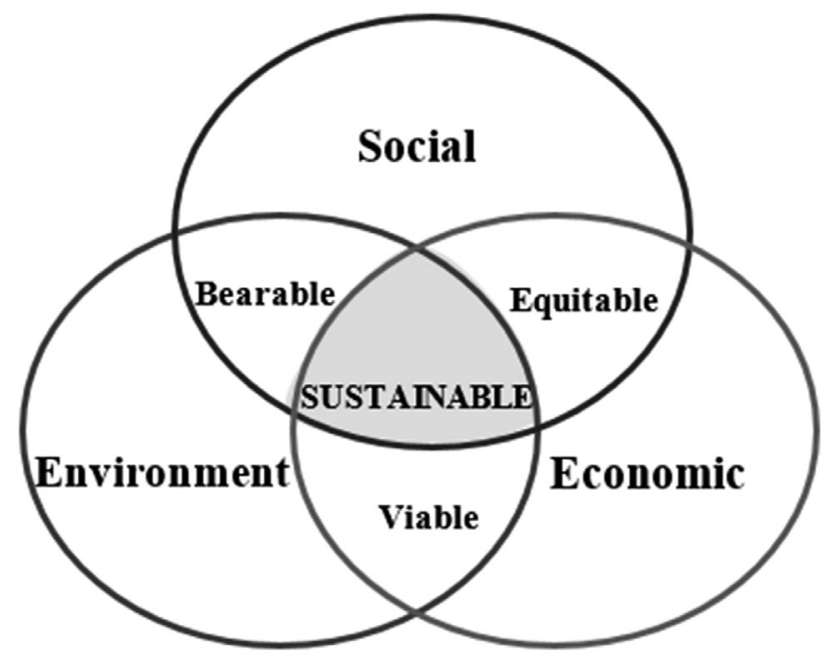

Figure 1. Triple-bottom-line

Source: Kunz, 2012

The choice of destination depends on the attractiveness of the destination, which is also influenced by waste approaches (Arbulu et.al., 2015), there is a non-linear and significant impact of the arrival of tourists, expenditure on tourism specialization and the share of tourism in MSW production. Similarly, Boys et al. (2017) appeals to the need to ,respect the sustainability of the destination, since customers who want to travel are more environmentally friendly, and the introduction of environmental and social programs is one of the criteria for choosing accommodation" (Boys, 2017).

Restauration and hotels are one of the main producers of the municipal waste (Kŕížek, 2014), primarily in the form of biological and mixed, whether it is waste in food processing, unused food, pizza boxes, glass and plastic. A step in reducing municipal waste is reducing food waste. Increased food production has an impact on biodiversity worldwide. It is obvious that increasing agricultural production leads to cultivation of monocultures and agricultural expansion into the rainforest areas, this is reflected in the loss of biodiversity, including mammals, birds, fish and amphibians. Furthermore, the tourism in the area of hotel and restaurant facilities is related to waste management, its controlled reduction, sorting, recycling options, the use of environmentally friendly products and improved consumption planning, respect for the waste management technology of the site etc. (MRD, 2006). In companies which apply social responsibility this mainly involves the introduction of recycling materials (packaging, bottles, organic packaging, straws, etc.). Both employees and customers can contribute to reducing the environmental im- 
pact of operations. The ,greening“ of hotel operations in the context of corporate social responsibility (CSR) shows the close links between CSR and hotel human resource management (Bogdanecz, 2005). Branco (2006) says, that the adoption of CSR is responsible for the increased productivity, loyalty, good reputation of workers and brings long-term competitive advantage.

\section{METHODS AND DATABASE}

There are a number of sets of indicators and criteria for assessing corporate social responsibility and sustainable business. The question of waste management is a part of many comprehensive indices and methodologies for assessing sustainable development, or CSR. As mentioned above, tourism businesses are concerned with the elimination of waste outbreaks, the reduction or recycling of waste (then its recovery). Subsequently, the Business Leaders Forum (Business Leaders Forum, 2019) indicator is used as a priority, it measures ecological corporate culture in the field of waste by an indicator „The Proportion of recycled waste”, or by inverse indicator "Amount of unsorted and misused waste". Eurostat maintains a set of EU sustainable development and resource efficiency indicators, which have been set to monitor progress sustainable development goals in EU (Eurostat Supports the DSGs, 2019).

Organizations using CSR are encouraged to implement the Environmental Management System (EMS) for the environment and incorporate the principles of ecological behavior into the thinking of the employees themselves. Introduction of Environmental Management System currently represents the most widespread way a business can declare implementing environmental protection into its strategies, that means the environmental impacts of products and services are also considered. This system can be implemented through EMAS programme or norm ISO 14001. Another indicator of ecological behavior is gaining the award of an eco-label, it means that the company has incorporated environmental requirements into its product (physical or service). Eco-label management today is an example of innovative hotel management (Dzida, 2006).

Secondary data from CENIA, EUROSTAT information databases were also used for the article. Due to insufficient data base, waste production according to NACE Rev. 2 will be analyzed (services, excluding services dealing with waste handling) and production of towns and municipalities, i.e. Municipal waste. For the description of the waste management the indicators MDR a Forum will be used, i.e. the share of waste recycling in the total waste production and the amount of waste generated. Approach of accommodation facilities to waste management issues was identified through a pilot questionnaire survey a due to the unwillingness of respondents to respond to these forms of data collection, also third -party research, Internet declarations of hotel facilities and the current situation of eco-hotels and registered businesses under EMAS or ISO 14001 and eco-labels. The analysis put forward a hypothesis as to whether Abdul said that there is a non-linear relationship between the number of tourists and the amount of municipal waste generated. The analysis is based on a comparison of EU regions with an emphasis on the Czech Republic.

\section{ANALYSIS WASTE IN REGION EU}

Approximately 2.427 billion tonnes of waste (safe and dangerous, generated by households and businesses were produced in the EU annually (2008) and after a period of decline since 2008, waste production continues to grow (2016 - 2.537 billion tonnes, Figure 2). Consumer behavior in the long run has contributed to the increase in waste production. 
The development of waste in Czech Republic between 2004-2016 was more balanced. Figure 2 . shows that the Czech Republic had an inverse development compared to the EU by 2012, since 2012 the Czech Republic's waste production has followed the EU development. Between 20142016, the growth rate of production in the Czech Republic was about 7\% higher than in the EU.
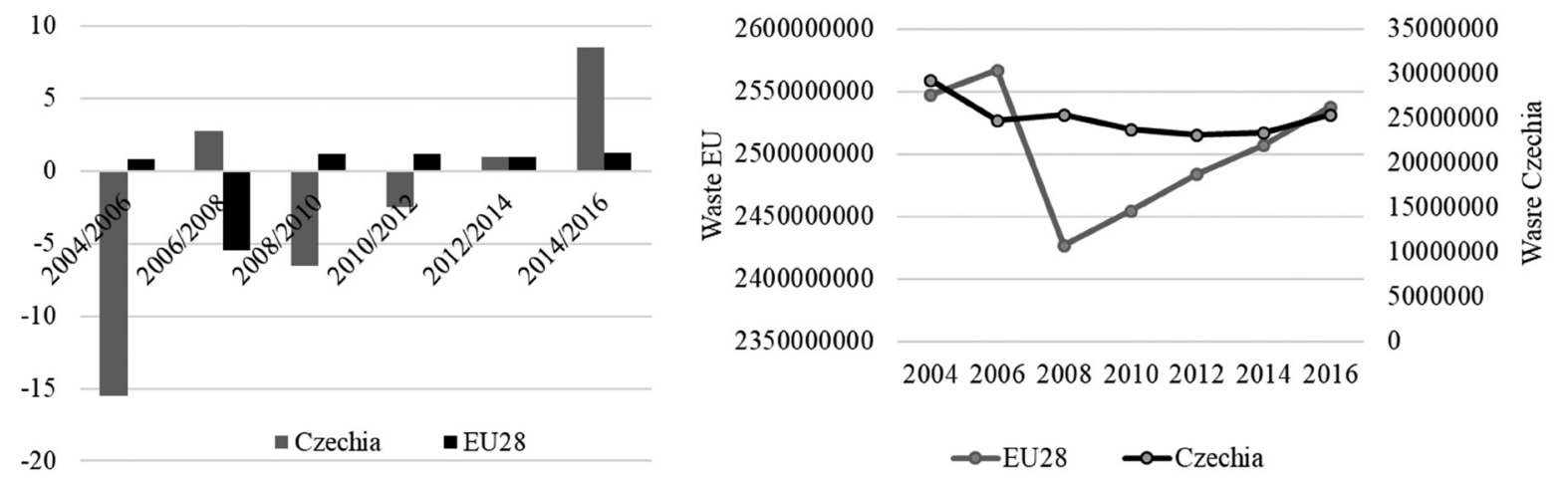

Figure 2. Annual change of production waste (household and NACE)

Source: Generation of waste by economic activity, 2019

The total amount of waste consists of business and household waste. The business activities of all NACE sectors are 91,54 \%, in 2008 it was 90,9\%. Latvia and Portugal had a higher share of households in total waste production. France, Spain, Romania and the United Kingdom had the lowest share of waste generation enterprises (Figure 3.). Cyprus, Lithuania and Malta share the least in the production of business waste within the EU28. Within the EU28, there is an increase in the production of business waste (between $2008 / 2016$ by $5,6 \%$ ). Latvia $(+87 \%)$, Sweden $(+67,8$ $\%$ ) and Finland (+ $51 \%$ ) accounted for a significant share of waste in growth between 2008/2016.

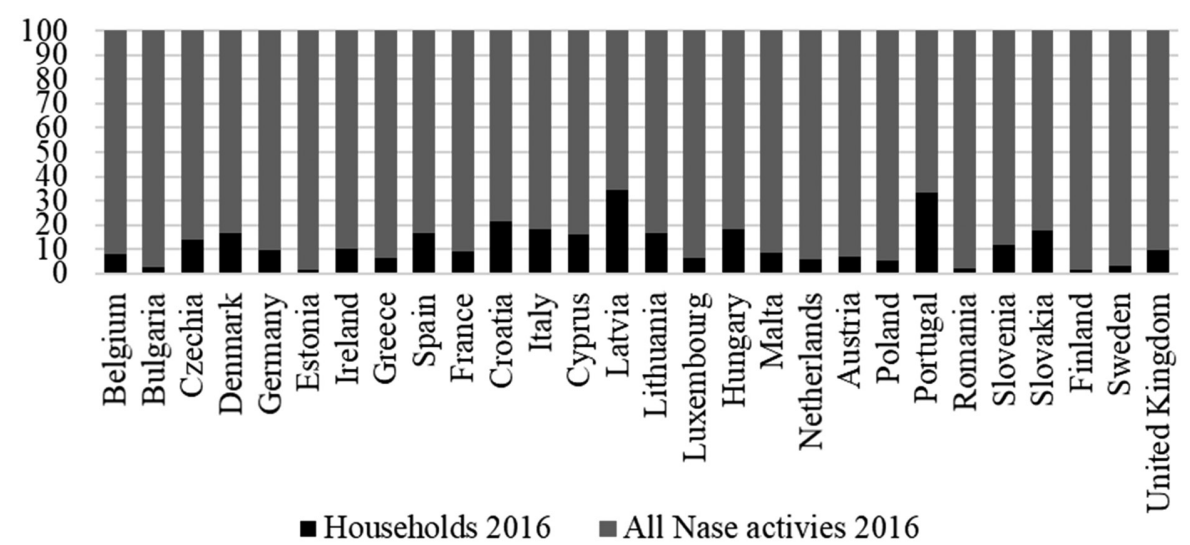

Figure 3. Share of households and enterprises of NACE in total waste, amount of household waste and enterprises of NACE in tonnes

Source: Generation of waste by economic activity, 2019

Conversely Ireland (34\% down), Bulgaria (28,6 \% down) and Spain (14\% down) dampen the increase in business waste between 2008 and 2016. The Czech Republic with an 86,73\% share of industry in waste, is one of the regions with and above average $(13,27 \%)$ share of households in waste production with values above the median (median 9,85\%). The share of Czech businesses in total waste production decreased compared to $2008(87,64 \%, 2008)$.

The amount of waste in the EU services sector has increased since 2008, after years of decline (Figure 4, Eurostat, Waste NACE, 2019). According to the forecast production in services will 
continue to grow. However, the service sector was not the source of the sharp increase in total waste after 2008. The focus of waste accumulation is industry, the largest producer of waste is construction. Services accounted for 5,8 \% of waste production in 2004 and their share in the total amount of waste is gradually decreasing, (except 2008, 6,1 \%), to 4,6 \% by 2016. The Czech Republic accounts for 0,91\% (2016) of the total EU waste production (businesses and households) of $1,0 \%$ in $2016,1,05 \%$ in 2008 , in the services sector, an increase of $0,24 \%$ compared to 2008 .
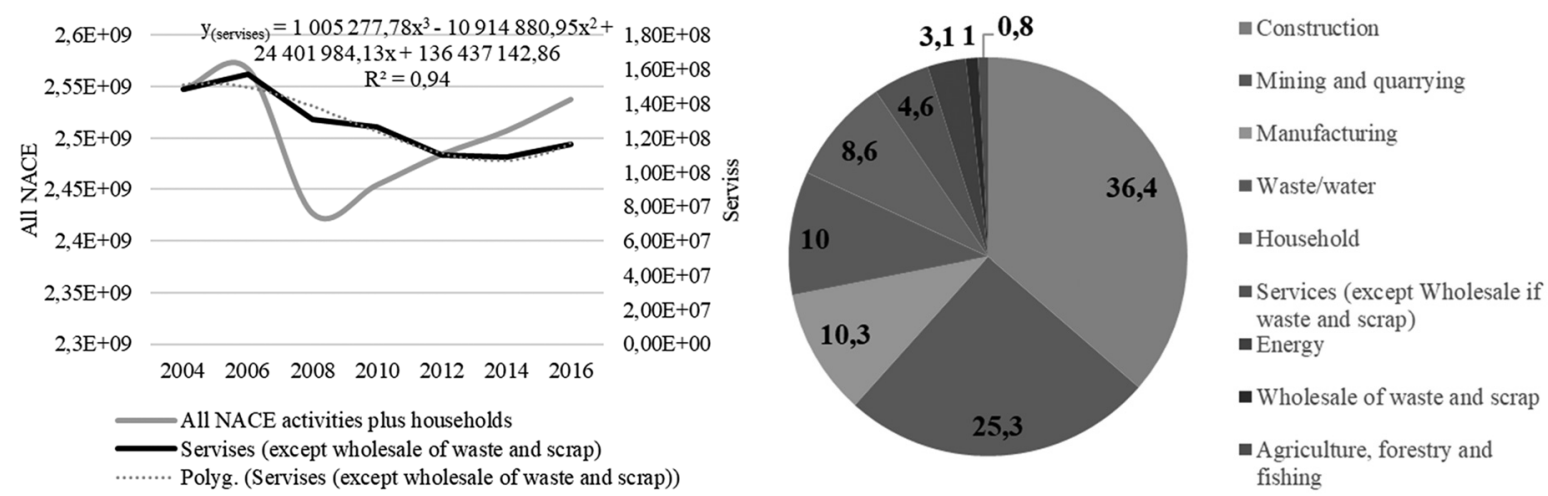

Figure 4. Waste in EU to 2004 - 2016, Services share in total waste production 2016

Source: Eurostat, Generation of waste by economic activity, 2019

\section{DEVELOPMENT OF MUNICIPAL WASTE IN EU}

As far as municipal waste is concerned, it accounts for only $10 \%$ of total waste production and its main sources are also construction, mining and quarrying, production, waste trades households (Figure 4), although they are only a fraction of the waste, the issue of management is far more complex. On average, $501 \mathrm{~kg}$ of municipal waste per person was produced in the EU28 in 2009 (a total of 256995 thousand tonnes in the EU). In 2017, the amount of municipal waste decreased to $468 \mathrm{~kg}$ per person, which was in total 248653 thousand tonnes in the EU (Eurostat, Waste municipality, 2019).

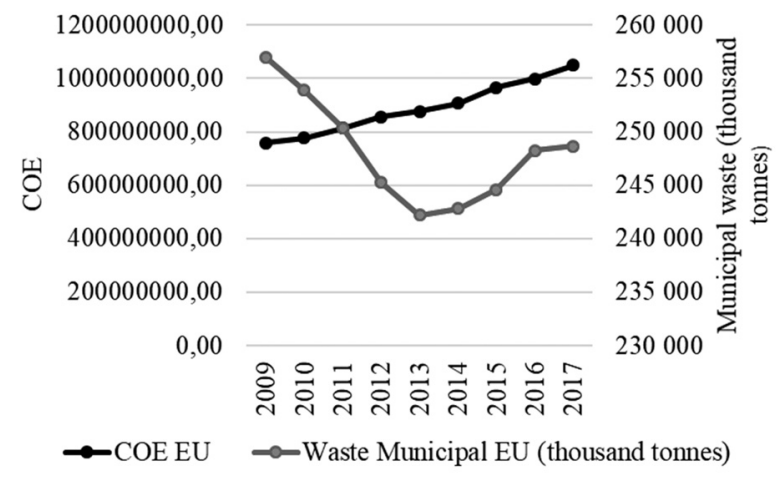

Figure 5. Municipal waste (in tonnes) and tourism in EU

Source: Municipal waste, 2019, Tourism 2019

In the case of EU, municipal waste the development of waste in the EU is not very different. The situation is similar in the Czech Republic; both curves have the same trajectory. The development of municipal waste in the EU tends to be shown in Figure 6. Although municipal waste accounts for only $10 \%$ of total waste generation, households are the main sources of waste. However, there are regions where the high values are due to tourists in regions, e.g. Cyprus, Malta or Croatia. 


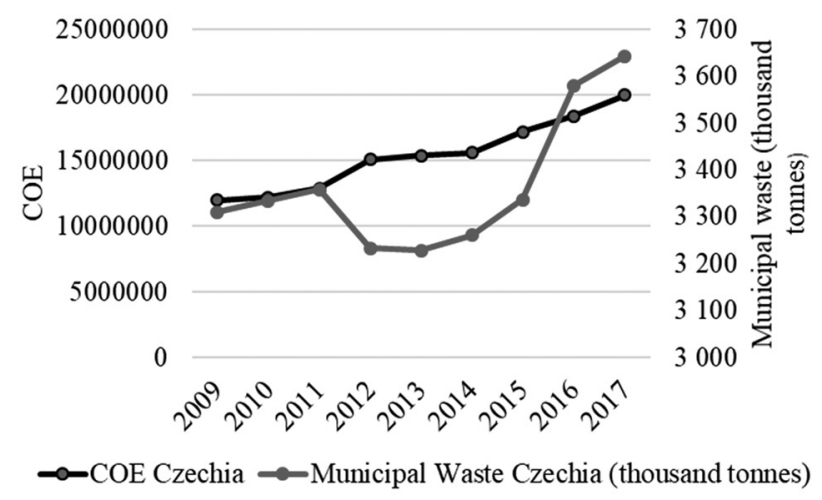

Figure 6. Municipal waste (in tonnes) and tourism in Czechia

Source: Municipal waste, 2019, Tourism, 2019

According to figure 7, the regions of Denmark, Cyprus, Germany, Luxembourg or Malta have the highest proportion of municipal waste per capita in the EU per capita, which is not the dominant country in the number of domestic and foreign tourists staying in the COE in 2017.
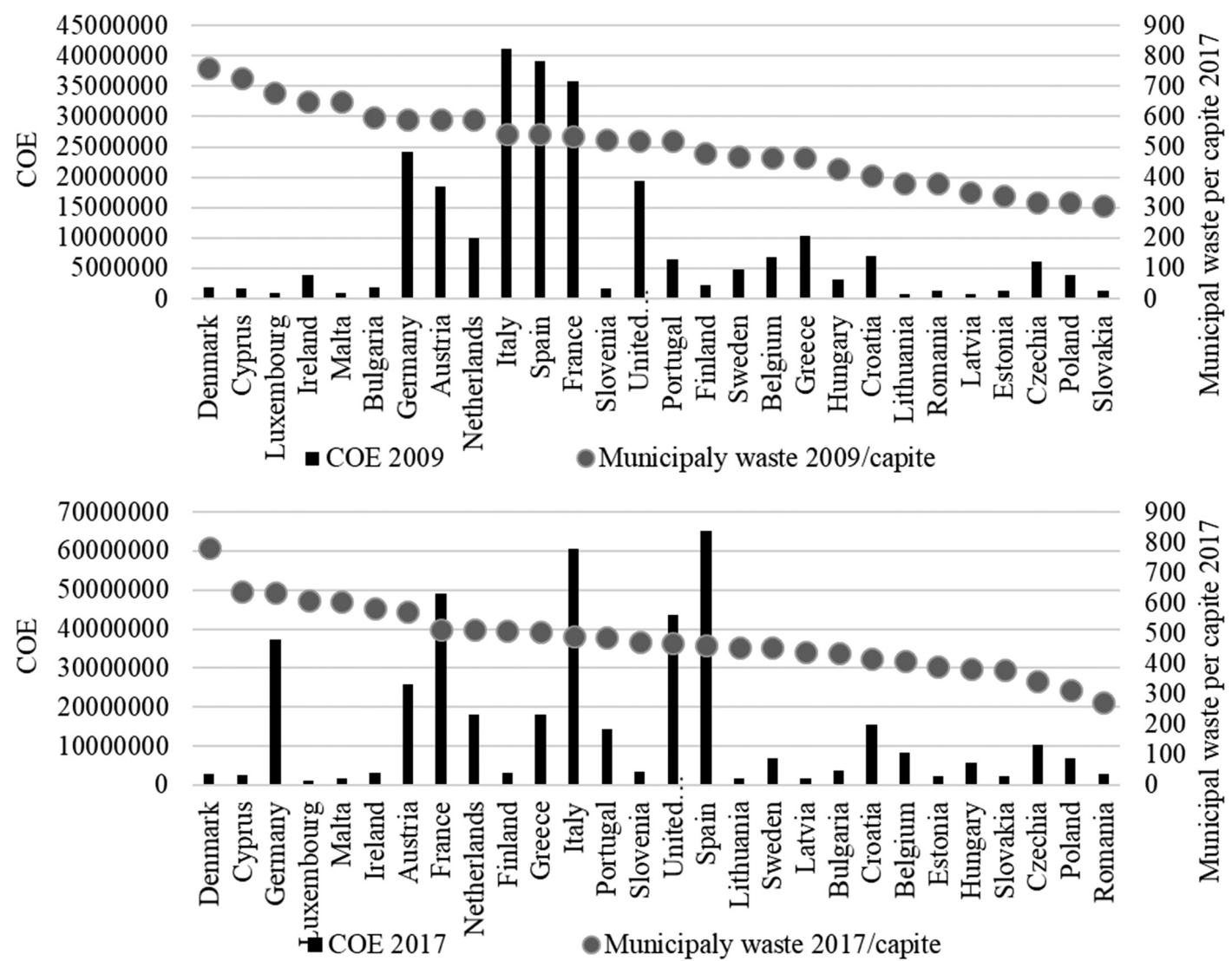

Figure 7. Municipal waste per capita and tourism in EU

Source: Municipal waste, 2019; Tourism, 2019

The Czech Republic was one of the regions of the EU with the lowest amount of municipal waste per capita, arranged before Poland, Romania. The Czech Republic maintained its position from 2009. Like Arbula (2015), they focused on finding relationships at the Czech level. A non-linear relationship was found between the number of tourists staying in collective accommodation facilities and the amount of municipal waste at the level of the Czech Republic. 
According to the model of the regression equation $(1,2)$, it is assumed that in the unchanged situation the municipal waste of the Czech Republic will increase in the future (minimum 14 476458 tourists in CAE, $\mathrm{R}^{2}$ (determination coefficient) =0,873; Durbin Watson 2,41 sig. model $<0.05$, see Figure 8 , Table $1^{3}$.

$$
\begin{aligned}
& y=b_{0}+b_{1} x_{1}+b_{2} x_{2}+e \\
& y=6,24 E+06-4,12 E-01 x+1,42 E-08 x^{2}
\end{aligned}
$$

Where:

$\mathrm{b}$ - parameter; e - deviation; $\mathrm{x}_{\mathrm{n}}$ - independent variable; $\mathrm{n}$ - 1;2;3...n; $\mathrm{y}$ - dependent variable

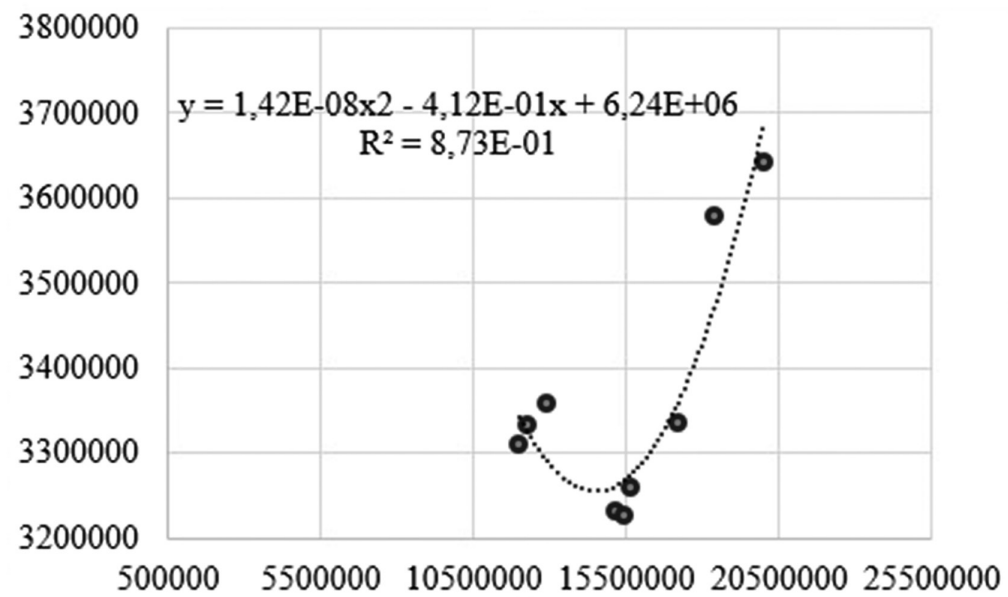

Figure 8. Regression analysis of number of tourists and volume of municipal volume

Source: Own processing

\begin{tabular}{|c|c|c|c|c|c|}
\hline & \multicolumn{2}{|c|}{ Unstandardized Coefficients } & \multirow{2}{*}{$\begin{array}{c}\begin{array}{c}\text { Standardized } \\
\text { Coefficients }\end{array} \\
\text { Beta } \\
\end{array}$} & \multirow[t]{2}{*}{$\mathrm{t}$} & \multirow[t]{2}{*}{ Sig. } \\
\hline & $\mathrm{B}$ & Std. Error & & & \\
\hline HUZ & -0.412 & 0.100 & $-7,721$ & $-4,113$ & 0,006 \\
\hline HUZ**2 & $1.423 \mathrm{E}-0.008$ & 0.000 & 8,414 & & \\
\hline \multirow[t]{2}{*}{ Constanta } & 6238856.73 & 773416.15 & & 8,067 & 0,000 \\
\hline & Sum of Squares & $\mathrm{df}$ & Mean Square & $\mathrm{F}$ & Sig. \\
\hline Regression & $1,503 \mathrm{E}+11$ & 2 & 76512203366 & 20.58 & 0,002 \\
\hline Residual & 22312482157 & 6 & 3178747026 & & \\
\hline Total & $1,753+11$ & 8 & & & \\
\hline
\end{tabular}

Table 1. Results of regression analysis of number of tourists and volume of municipal volume

Source: Own processing

\section{DEVELOPMENT OF MUNICIPAL WASTE RECYCLING IN EU}

The proportion of the EU28 municipal waste recycling is 46,4\% in 2017 and has been gradually increasing since 2009. On the positive side, the continued increase in municipal waste recycling has pushed the EU towards the 2030 goal (EUROSTAT, 2019). By 2025, the proportion of recycled waste in the EU should increase to $55 \%$, and by 2030 to $65 \%$.

3 The model is well chosen with respect to the achieved values 
Germany $(67,7 \%)$ has the most active approach to municipal waste recycling and it is also the largest producer of municipal waste in the EU28. In addition, Austria (57,7\%), Slovenia (57,8 \%) and Netherlands (54,2\%), these countries have low levels of municipal waste and they belong to the recycling dominators. Malta had the lowest share of municipal waste recycling in total waste in $2017(6,4 \%)$.

Other countries with a low share include Romania (13,9 \%), Cyprus (16,1 \%) and Greece $(18,9$ $\%$ ). The Czech Republic is below the EU28 average and median (average 37,71 \%, median 37,75 $\%$ ). The increase in the share municipal waste recycling is more dynamic in the EU than in the Czech Republic. If we evaluate the development of the recycling ratio (Figure 9.) then it is obvious that Slovakia, Croatia, Romania or Lithuania increased, the regions of Austria, Belgium, Denmark and Sweden decreased.

On the other hand, Latvia has greatly improved its position. Within the Visegrad Four, Czechia maintains the best position throughout 2009-2017. The Czech Republic ranks 7th in the share dynamics (increase by $157 \%$ ).
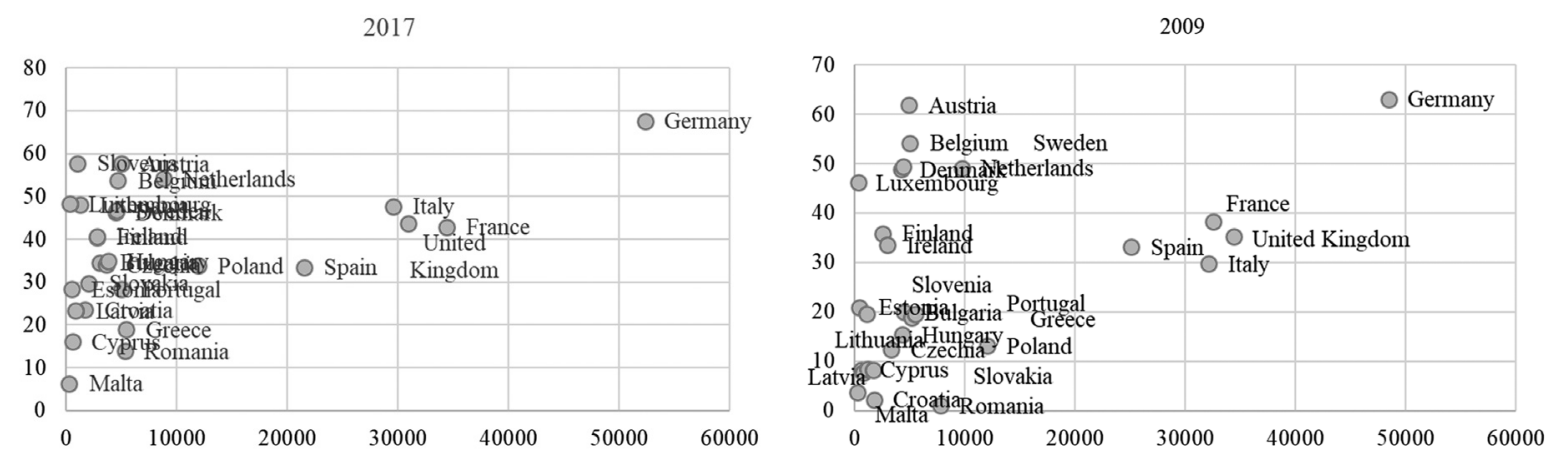

Figure 9. Share of municipal waste recycling and municipal waste volume in 2017 and 2009

Source: Own processing, x volume of municipal waste; y recycling share municipal waste

It is clear from Figure 10 that even here, it is not possible to prove a link (linear dependence) between the proportion of municipal waste recycling and the volume of tourists staying in collective accommodation establishments. When evaluating the share of recycling in the number of tourists, there is no obvious dependence. Countries with intensive tourism realize both active and passive waste management policy in the form of recycling rates. For example, Luxembourg with a lower value of tourists shows relatively high recycling rates, similar to Bulgaria, compared to Spain, Italy or France.

In terms of summarizing the evaluation of the quantities of municipal waste per capita, municipal waste volume in tonnes and recycling rate, Figure 11 shows the position of individual EU regions. The $\mathrm{x}$-axis expresses the situation in 2017 and the y-axis expresses dynamics as a year-on-year change in 2017/2009 (Kahoun, 2010). Development suggests that regions such as Slovenia, Hungary and Bulgaria or Romania are in the II. Quadrant (Step Leading Step).

In Europe, the dominant Germany, together with Greece, Denmark and France (Quadrant III - Continued decline) lose a good position and fall. The Czech Republic is (along with eight other EU countries) in the IV quadrant (losing a lead), similar to Slovakia. The Czech Republic gained its position due to higher values of waste growth dynamics per capita and total volume. 

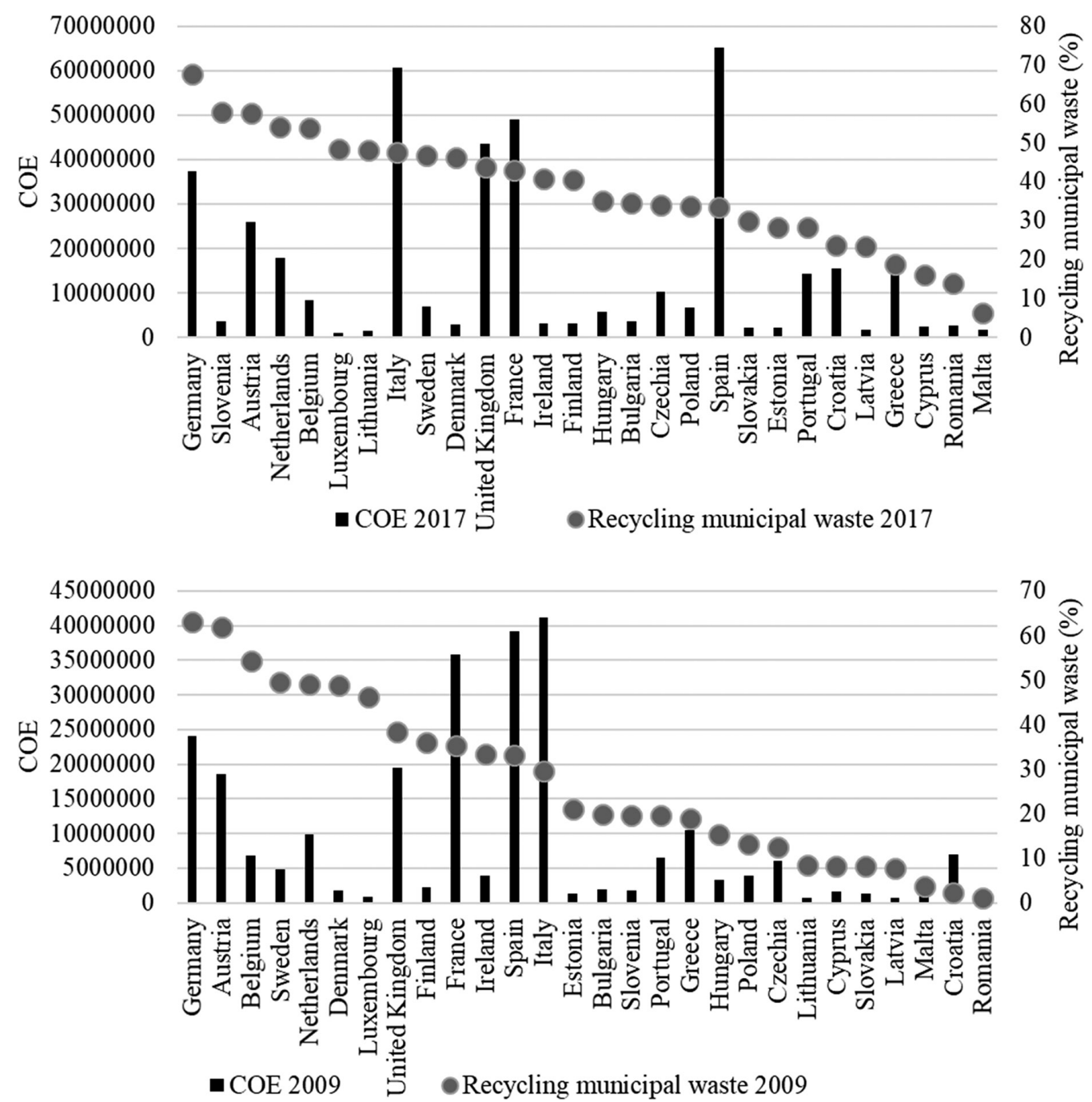

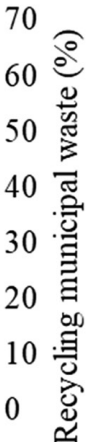

Figure 10. Share of municipal waste recycling 2009 and 2017

Source: Own processing, data Recycling municipal waste, 2019; Tourism, 2019

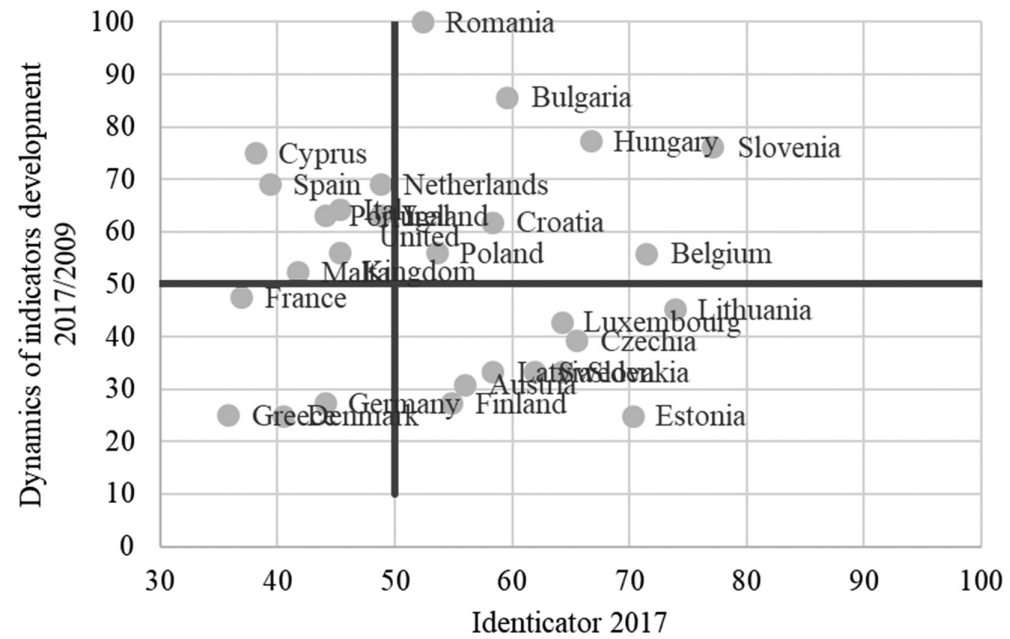

Figure 11. Position of EU regions

Source: Own processing, method Kahoun, J. \& Kadeřábková, A., 2007 


\section{IMPLEMENTATION OF ECOLOGICAL MANAGEMENT IN EU REGIONS WITH EMPHASIS ON THE CZECH REPUBLIC}

In the "Waste Management Plan of the Czech Republic for 2015-2024" (Ministry of the Environment, 2014) the Czech Republic set to recycle $46 \%$ by 2016 and $50 \%$ by 2020 . Above all, it is about reducing municipal waste of commercial subjects. The Czech Republic is trying to meet the obligations arising from the EU Commission proposal in advance. The Czech Republic's goal is to ban landfilling of untreated mixed municipal waste by 2024, which is 6 years earlier than proposed in the current strategy for circular economy within the EU. In addition, the Ministry proposes to introduce a ban on landfilling recyclable and combustible waste (with a net calorific value above $4 \mathrm{MJ} / \mathrm{kg}$ ). Some stakeholders are concerned that the combination of these measures will lead to the excessive development of incinerators at the expense of recycling and reuse of raw materials.

A survey in 12 EU countries (RAVE, 2017, Table 2) showed that EMAS is one of the options for achieving the target; the majority of respondents attached great importance to the introduction of EMAS on the issues of the circular economy. The problem with the reluctance to register EMAS or ISO in the Czech Republic is in regulation. However, the Czech Environmental Regulatory Authority has expressed significantly greater confidence in EMAS and sees no reason why EMAS registered organizations should not receive greater regulatory relief. The advantage of registration is the administrative simplicity of reporting annual declarations. For enterprises with EMAS registration or ISO 14001 certification, it is sufficient to submit either an environmental statement or an EMS certificate.

Table 2. Potential to better integrate EMAS into existing policies to help public authorities achieve their environmental objectives in priority areas

\begin{tabular}{|l|c|}
\hline Policy area & Value \\
\hline Circular Economy & 4,4 \\
\hline Waste & 4,4 \\
\hline GHG emissions and climate change & 4,4 \\
\hline Consumer information (on the environmental performance of product and organisations & 4,3 \\
\hline Air pollution & 4,2 \\
\hline Noise & 4,1 \\
\hline Water pollution & 4,0 \\
\hline Environmental impact assessment & 4,0 \\
\hline Non-financial reporting & 3,8 \\
\hline Chemicals, human health and the environment & 3,8 \\
\hline Nature and Biodiversity & 3,7 \\
\hline Land, Marine and Coast preservation & 3,5 \\
\hline
\end{tabular}

Source RAVE, 2017

Undertakings without registration must specify a system for carrying out pollutant release and waste management and how to avoid environmental damage. ISO 14001 (including energy audit) or ISO 5001 certified companies do not need to perform an energy audit every 4 years. If we consider that only those companies that have implemented EMAS systems, ISO 14001 (Survey, 2019) standards or hold the certificate Eco-friendly service behave environmentally, then the situation in accommodation services and restaurants in the Czech Republic would be very poor. Currently, in the Czech Republic out of a total of 25 registered enterprises in 2017 (20 in 2019), no hotel or other accommodation facility has registered EMAS (environmental declaration verification). In contrast, in the EU there are 199 establishments in accommodation establishments 
in 2017 (2019; 187 establishments, (see table 3). NACE 55 companies took advantage of the possibility to implement in their management in 2006 in 9 cases (NACE H) of ISO 14001 (certification), a total of 2122 enterprises were registered, in 2018 there was a decrease. They are mostly large businesses, hotel chains (for example Mc Donald).

Table 3. Potential to better integrate EMAS and ISO 14001 into existing policies to help public authorities achieve their environmental objectives in priority areas

\begin{tabular}{|l|c|c|c|c|}
\hline \multicolumn{1}{|c|}{ Organizations } & $\begin{array}{c}\text { Number of company registrations Share in } \\
\text { registrations within enterprises }\end{array}$ & $\begin{array}{c}\text { Number of company registrations Share in } \\
\text { registrations within enterprises (in \%) }\end{array}$ \\
\hline & EU & CZ & EU & CZ \\
\hline EMAS (55) & 187 & 0 & 0,011 & 0 \\
\hline EMAS * & 3728 & 20 & 0,01526 & 0,00692 \\
\hline ISO 14001 (55) & 2106 & 7 & 0,10538 & 0,00005 \\
\hline ISO 14001* & 68950 & 3925 & 0,28228 & 0,26606 \\
\hline
\end{tabular}

Source: EMAS 2019
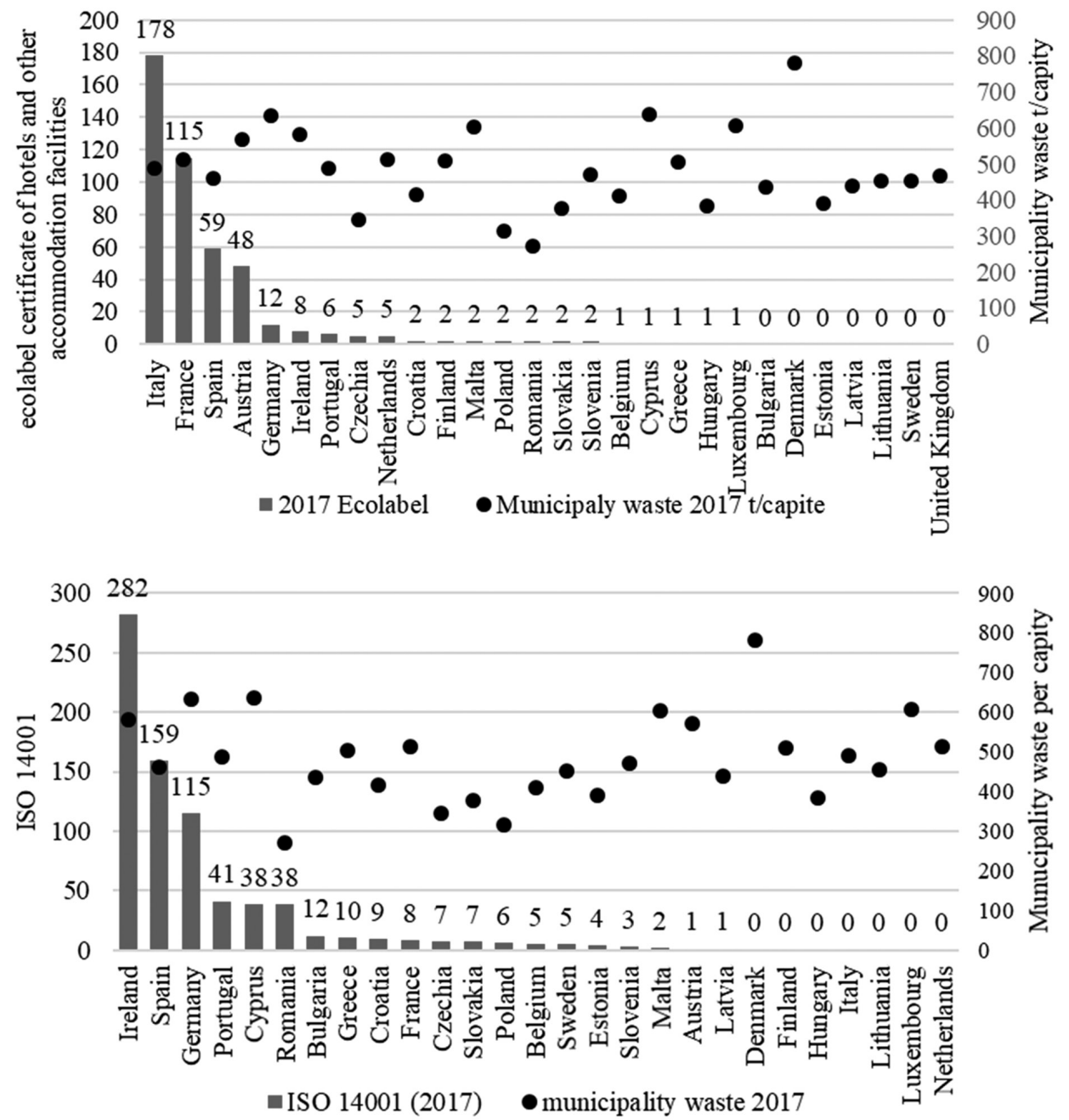

Figure 12. Registration Ecolabel EU and ISO 14001 in NACE H - municipality waste in 2017 Source: Own processing, data Municipality waste 2019, Survey, 2019

Regarding the award of eco-labels, in 2017 (see figure 12) 454 accommodation establishments were registered in the EU, i.e. $20.95 \%$. Italy, France and Spain play the first place in the field of certification. 
Currently (2019) has 469 hotels listed. In the case of the Czech Republic, 5 hotel establishments were certified in 2017, which has been a decrease by two certifications since 2008. In 2019, only one company is registered on the Ecolabel website, namely the Centre of Environmental Education and Ethics Rýchory-NORTH. According to fig. 12, it is clear that the scope of certified environmental accommodation services does not guarantee a low level of municipality waste per person.

Another brand that can be acquired by accommodation and catering companies in the framework of the provision of services is the Czech eco-label "Green Eco-label". A total of 205 certifications were registered in 2008, 7 related to hotels. Three of them also owned the Ecolabel certification. The number of registrations is decreasing; the decrease also applies to hotel facilities. In 2014 there were only tree hotels (see Tab. 4).

Table 4. Statistics eco-friendly product/service in Czechia (2006-2017)

\begin{tabular}{|c|c|c|c|c|c|c|c|c|c|c|}
\hline & $\stackrel{\infty}{\stackrel{\leftrightarrow}{\sim}}$ & ڤे & $\stackrel{\circ}{\stackrel{2}{*}}$ & $\overline{\bar{\Gamma}}$ & $\stackrel{\text { ปี }}{2}$ & $\stackrel{m}{\stackrel{n}{i}}$ & $\stackrel{4}{\stackrel{4}{d}}$ & $\stackrel{n}{\stackrel{2}{2}}$ & 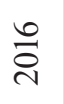 & $\overline{\check{\overbrace{}}}$ \\
\hline Valid Ecolabel licenses & 205 & 207 & 192 & 185 & 98 & 90 & 92 & 83 & 72 & 51 \\
\hline $\begin{array}{l}\text { Product groups with applicable Ecolabel criteria in } \\
\text { place }\end{array}$ & 59 & 62 & 64 & 43 & 37 & 36 & 30 & 20 & 18 & 20 \\
\hline Eco-label holders (manufacturers, importers, etc.) & 92 & 92 & 102 & 88 & 56 & 56 & 56 & 51 & 45 & 39 \\
\hline
\end{tabular}

Source: Statistical Environmental Yearbook of the Czech Republic, 2019

\section{EXAMPLES OF PRACTICE}

Do you environmentally friendly in Czech hotels? A total of 16 hotels were evaluated in the pilot survey (see figure 13). Research has shown that hotels are trying to solve the problems of waste management according to their own beliefs and possibilities, among the hotels of non-EMAS certified businesses. Internet information shows businesses that have permission to manage unnecessary certificates or standards, but when using environmentally friendly means intuitive and common sense.

All hotel businesses sort waste, only one hotel replied that it sorts partially. In most cases, waste is sorted in the background of the facility. Only one hotel reports that they are already sorting in hotel rooms. Two $4 *$ hotels are considering introducing this alternative.

The responses show that hotels recycle waste partially. Up to $50 \%$ do not recycle, $25 \%$ only partially and only 2 hotels report recycling. After a consultation, however, it is mainly composting. As mentioned above, the reduction of the global problem should not be approached only by the subsequent treatment of waste but by an effort to prevent its generation. According to the piloting, it is clear that hotel companies are trying to effectively buy and train employees to use food effectively in preparation and cooking, but also to sort solid waste.

The problem is that even though employees are trained, they do not adopt an ecological lifestyle. In two hotels, there was a problem with keeping the sort. The monitored enterprises are trying to refrain from disposable packaging of delicacies (mustard, ketchup, honey, etc.), disposable packaging uses very few devices. Also, disposable plastic dishes (plastic cups, paper trays) are also minimally used. 
Are employees encouraged to reduce waste when preparing and cooking food?
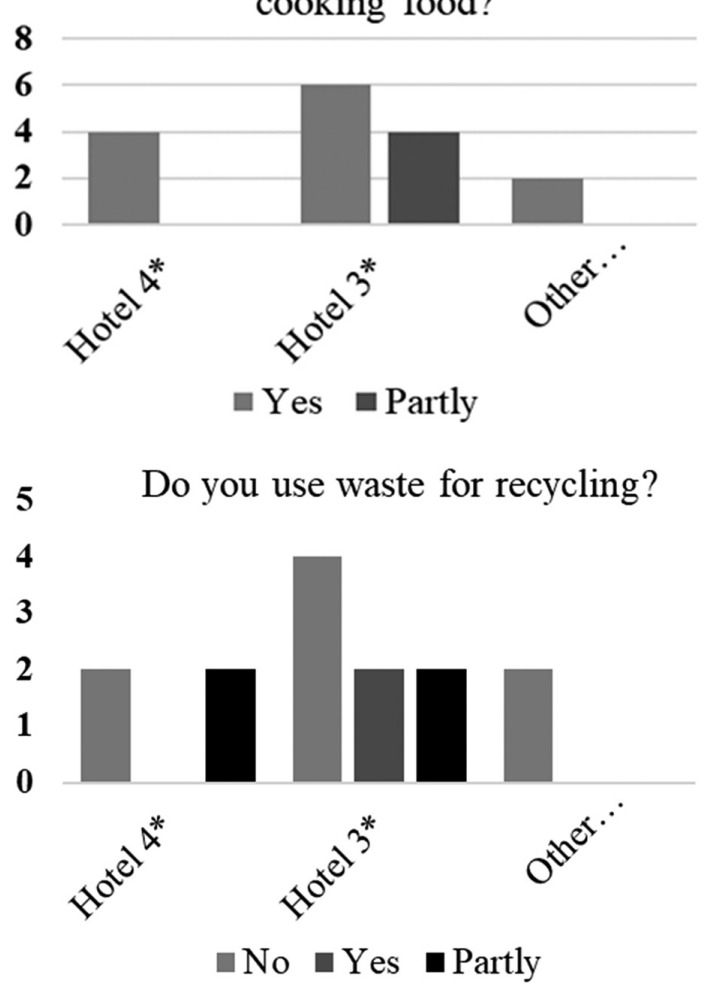

Do we use disposable products

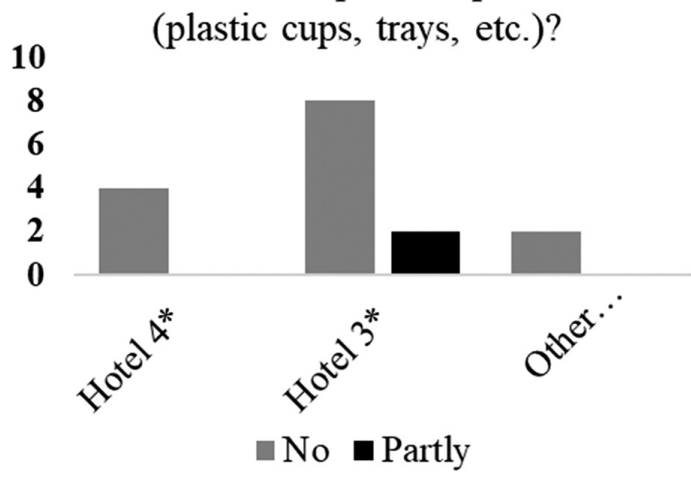

Are you trying to reduce waste by purchasing effectively?

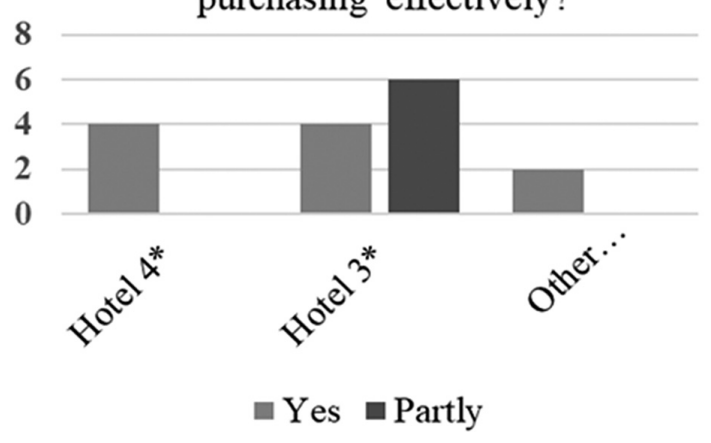

Do you use disposable packaging (mustard, honey, etc.)?

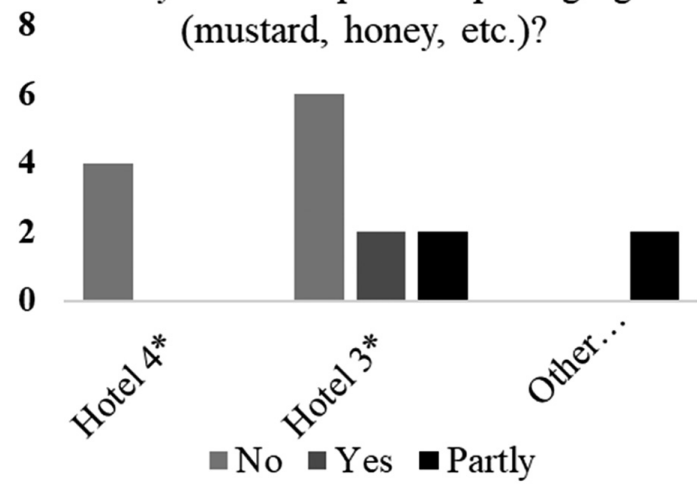

Is the company registered with 10 EMAS?

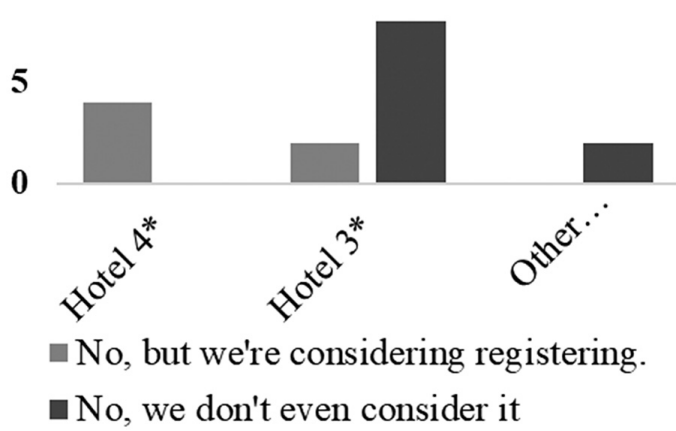

Figure 13. Survey

Source: Own processing

For example, Hotel Mandarin (Hotel Mandarin, 2019) uses pallets to make furniture and uses hotel slippers to make Christmas decorations. Hotel Augustinian House sorts all types of waste and tries to reduce it. To reduce paper waste, guests were asked to sign the jars to help reduce waste production. The consumption of these cups decreased three times. Balance Club Praha (BalanceClub Praha, 2019) consumes 84,300 disposable cups and 200,000 plastic bags per year, over a million paper towels. To reduce plastic dishes and disposable cups, they will use reusable cups, reduce the use of plastic straws, offer the option of serving drinks in their own delivered containers, expand bio-waste containers and Phenol Free eco-receipts, and increase employee educational activities. As part of sustainability and social responsibility, the Hilton Prague (Idnes, 2019) has undertaken to recycle all used soaps from 15th October 2019, which will then be shipped mainly to third world countries. The initiative is intended to help prevent the spread 
of diseases and to serve as an example of how to waste resources, another step in the Hilton hotel chain, after the existing recycling of shampoo and other cosmetics packaging and unnecessary mattresses. In the Czech Republic, McDonald's restaurants (McDonald's, 2018) sort all packaging from customers in restaurants. They recycle packaging from suppliers, paper packaging from food sold to customers. McDonald's recycled $56 \%$ of the packaging materials and another $34 \%$ were processed by energy recovery. In addition, most of the packaging shipped by Czech McDonald's restaurants is made from recycled materials. The main benefit of these steps is the reduction of landfilling and the subsequent further expansion of landfills, which seems to be an increasing problem not only in the Czech Republic but also abroad. McDonald removes the packaging for the return journey. On the second part, by changing plastic drinking straw to paper drinking straw, increases waste for waste combustion, which is not in accordance with EU or Czechia policy.

\section{CONCLUSION}

The results analysis show disparities between EU countries. In the Czech Republic, as in the EU, the amount of municipal waste is growing. Poland and Romania have the most municipal production waste per capita; the Czech Republic has position above average between regions of the EU. However, if we assess the service sector where accommodation and restaurants belong, their share in the generation of total waste is reduced. Similarly to the development of waste generation in the EU28 in the services sector, the share of waste from services in the Czech Republic is below the European average. The year-on-year increase in waste generated by services in Czechia (dynamics 120.6\%; 2014/2016) is faster than in the EU28 (106.7\%; 2014/2016). The year-on-year change between 2016/2008 has an inverse character (EU28 88\%, Czechia 101.4\%). The position of the Czech Republic is not favorable within the summary of selected indicators of waste management, consideration should be given to eliminating the increase in the total amount of municipal and per capita waste. The growth rate of total waste is faster than in the EU28.

Companies have many options for adopting environmental management. One of them is the implementation of EMAS or the ISO 14001 standard. In Czech conditions, as in research (Seggara, 2011), only a small proportion of small hotels in restaurants consider adopting sustainable solid waste management practices, although acceptance would be appropriate. By accepting the hypothesis, it can be stated that there is a non-linear relationship between the amount of waste and the number of tourists and that as the number of tourists increases, the amount of municipal waste produced increases, still many businesses have a negative approach to implementing CSR (Radvan, 2012). The share of eco-labelled enterprises in the Czech Republic has been gradually decreasing. According to hotel research and information, hotel complexes are trying to take on corporate social responsibility, but are reluctant to invest time and money in certification and building a management system. Businesses usually implement a social responsibility policy to their best conscience. However, there is a need to adopt a systemic management of CSR and also to increase State support (Radvan, 2010). A systemic solution to corporate social responsibility is a step towards creating sustainable development, as stated by Frans Timmermans, President of the European Commission (Barend, 2019).

\section{„Our planet and our economy cannot make it possible to survive if we further implement the take-and-throw approach."}




\section{ACKNOWLEDGMENT}

This paper is an output of the science project SGS 2/2019 "Tourism of the Moravian-Silesian Region in the context of sustainable development" Faculty of Philosophy and Science in Opava, Department of Spa, Gastronomy and Tourism in Opava.

\section{REFERENCES}

Arbulu, I., Loyano, J., \& Rez/Maguieira, J. (2015). Tourism and solid waste generation in Europe: A panel data assessment of the Environmental Kuznets Curve. Waste Management, 46, 628636. DOI: 10.1016/j.wasman.2015.04.014

BalanceClub Praha. [Online]. In Social Responsibility Association 2019-09-12 [2019-7-14]. Available from: http://www.spolecenskaodpovednostfirem.cz/obsah/1199/balance-club-brumlovka-zavadi-nova-ekologicka-opatreni/

Barend, L. (2019). Common sense, common Europe", speech by President-elect Charles Michel at the University of Amsterdam. [online] 2019 [20-10-2019] Available from: https://www. consilium.europa.eu/en/press/press-releases/2019/11/20/common-sense-common-europespeech-by-european-council-president-elect-charles-michel-at-the-university-of-amsterdam

Bohdanowicz, P., Zientara, P., \& Novotna, E., (2011). International hotel chains and environmental protection: an analysis of Hilton's we care! Programme. (Europe, 2006-2008), Journal of Sustainable Tourism, 19(7), 797-816. DOI: 10.1080/09669582.2010.549566

Boys, K. A., White, K.D., \& Groover, G., (2017). Fostering rural and agricultural tourism: exploring the potential of geocaching. Journal of Sustainable Tourism, 25(10), 1474-1493. DOI: $10.1080 / 09669582.2017 .1291646$

Branco, M. C., \& Rodrigues, L. (2006). Corporate social responsibility and resource-based perspectives. Journal of Business Ethics, 69(2), 111-132. DOI: 10.1007/s10551-006-9071-z

Business Leaders Forum.: Co je CRS [online]. 2019 [cit. 2019-9-26]. Dziuba, R. (2016). Sustainable development of tourism - EU Ecolabel standards illustrated using the example of Poland. Comparative economic research-Central and Eastern Europe, 19(2), 111-128.

Cenia: Statistical Environmental Yearbook of the Czech Republic. [Online]. 2019 [cit. 2019-07-4]. Available from: https://issar.cenia.cz/publikace-o-stavu-zivotniho-prostredi/statisticka-rocenka-zivotniho-prostredi-cr/

Eurostat: EMAS. [Online]. [cit. 2019-07-4]. Available from: https://ec.europa.eu/environment/ emas/emas_registrations/statistics_graphs_en.htm

Idnes: End of waste. Hilton hotels want to recycle a million pieces of soap. [online]. 2019 [cit. 20199-26]. Available from: https://www.idnes.cz/ekonomika/podniky/hilton-recyklace-mydlo. A190319 095426 ekoakcie svob/diskuse

Eurostat: Generation of waste by economic activity. [Online]. 2019 [cit. 2019-07-4]. Available from: https://ec.europa.eu/eurostat/databrowser/view/ten00106/default/table?lang=en

Eurostat: Supports the DSGs. Sustainable development in the European Union Monitoring report on progress towards the SDGs in an EU context. [Online]. 2019 [cit. 2019-07-4]. Available from: https://ec.europa.eu/eurostat/web/products-statistical-books/-/KS-02-19-165

Eurostat: RAVE. Reinforcing Added Value for EMAS. [Online]. 2019 [cit. 2019-08-4]. Available from: https://ec.europa.eu/environment/emas/pdf/other/RAVE\%20final\%20report.pdf

Eurostat: Recycling rate of municipal waste. [Online]. 2019. [2019-07-4]. Available from: https:// ec.europa.eu/eurostat $/ \mathrm{tgm} / \mathrm{table} . \mathrm{do} ? \mathrm{tab}=$ table \&init $=1 \&$ language $=$ en $\&$ pcode $=\mathrm{t} 2020$ rt120\&plugin $=1$ 
Eurostat: Tourism. Arrivals at tourist accommodation establishments [Online]. 2019 [cit. 2019-074]. Available from: https://appsso.eurostat.ec.europa.eu/nui/show.do?dataset=tour_occ_arnat\&lang=en

Eurostat: Waste municipality [Online]. 2019 [cit. 2019-07-4]. Available from: https://appsso.eurostat.ec.europa.eu/nui/show.do?dataset=env_wasmun\&lang=en

In Idnes: McDonalds. Our paper straws cannot be recycled, McDonald's admitted. For plastic, it was possible [Online]. 2018-08-05 [cit. 2019-07-04]. Available from: https://www.idnes. cz/ekonomika/zahranicni/mcdonald-s-brcko-papir-recyklace-odpad.A190805_131019_ eko-zahranicni_mato

Kelly, J., Haider, W., Wiliams, P.W., \& Englund, K. (2007). Stated preferences of tourists for eco-efficient destination planning options. Tourism Management, 28(2), 377-390. DOI: 10.1016/j.tourman.2006.04.015

Kunz, V. (2012) Společenská odpovédnost firem. Praha: Grada Publishing,

Křížek, F., \& Neufus, J. (2014). Moderní hotelový management, Praha: Grada Publishing

Kahoun, J., \& Kadeřábková, A. (2007). Regionální konkurenceschopnost [online]. Centrum ekonomických studií-CESVSEM.cz. [cit 25-07-2017]. Available from: http://old.nvf.cz/rozvoj_ lz/dokumenty/regional_konkurence.pdf

Ministry of the Environment: Waste Management Plan of the Czech Republic 2015-2024. [Online]. 2019 [2019-7-14]. Available from: https:/www.mzp.cz/cz/plan_odpadoveho_hospodarstvi_cr

Ministry for Regional Development (MDR). [Online]. 2016. [cit. 2019-07-4]. Available from: http://www.mmr.cz/getmedia/cc80193b-e4e8-4694-8a65-728df70a5fd8/GetFile14_2.pdf

Radwan, H. R. I., Jones, E., \& Minoli, D. (2010). Managing solid waste in small hotels. Journal of sustainable tourism, 18(2), 175-190. DOI: 10.1080/09669580903373946

Radwan, H. R. I., Jones, E., \& Minoli, D. (2012). Solid waste management in small hotels: a comparison of green and non-green small hotels in Wales. Journal of Sustainable Tourism, 20(4), 533-550. DOI: 10.1080/09669582.2011.621539

Santamaria, A.J.R. (2016). The sectoral reference document for tourism in the European eco-management and audit scheme (EMAS). Actualidad Juridica Ambiental, 59, 3-17

Seggara-One, M.D., Peiro-Signes, A., Verma, R., \& et al. (2011). Does Environmental Certification Help the Economic Performance of Hotels? Evidence from the Spanish Hotel Industry. Cornell Hospitality Quarterly, 53(3), 242-256. DOI: 10.1177/1938965512446417

Survey ISO 14001. [Online]. In Content Server. [2019-07-4]. Available from: https://isotc.iso.org/ livelink/livelink? func=11\&objId=18808772\&objAction=browse\&viewType $=1$ 